University of Nebraska - Lincoln

DigitalCommons@University of Nebraska - Lincoln

\title{
Effects of Oxide Coating and Selected Cations on Nitrate Reduction by Iron Metal
}

Yong $\mathrm{H}$. Huang

University of Nebraska - Lincoln

Tian Zhang

University of Nebraska - Lincoln, tzhang1@Unl.edu

Patrick J. Shea

University of Nebraska - Lincoln, pshea1@unl.edu

Steve D. Comfort

University of Nebraska - Lincoln, scomfort1@unl.edu

Follow this and additional works at: https://digitalcommons.unl.edu/civilengfacpub

Part of the Civil Engineering Commons

Huang, Yong H.; Zhang, Tian; Shea, Patrick J.; and Comfort, Steve D., "Effects of Oxide Coating and Selected Cations on Nitrate Reduction by Iron Metal" (2003). Civil Engineering Faculty Publications. 22. https://digitalcommons.unl.edu/civilengfacpub/22

This Article is brought to you for free and open access by the Civil Engineering at DigitalCommons@University of Nebraska - Lincoln. It has been accepted for inclusion in Civil Engineering Faculty Publications by an authorized administrator of DigitalCommons@University of Nebraska - Lincoln. 


\title{
Effects of Oxide Coating and Selected Cations on Nitrate Reduction by Iron Metal
}

\author{
Yong H. Huang, Tian C. Zhang,* Patrick J. Shea, and Steve D. Comfort
}

\begin{abstract}
Under anoxic conditions, zerovalent iron $\left(\mathrm{Fe}^{0}\right)$ reduces nitrate to ammonium and magnetite $\left(\mathrm{Fe}_{3} \mathrm{O}_{4}\right)$ is produced at near-neutral $\mathrm{pH}$. Nitrate removal was most rapid at low pH (2-4); however, the formation of a black oxide film at pH 5 to 8 temporarily halted or slowed the reaction unless the system was augmented with $\mathrm{Fe}^{2+}, \mathrm{Cu}^{2+}$, or $\mathrm{Al}^{3+}$. Bathing the corroding $\mathrm{Fe}^{0}$ in a $\mathrm{Fe}^{2+}$ solution greatly enhanced nitrate reduction at near-neutral $\mathrm{pH}$ and coincided with the formation of a black precipitate. $X$-ray diffractometry and scanning electron microscopy confirmed that both the black precipitate and black oxide coating on the iron surface were magnetite. In this system, ferrous iron was determined to be a partial contributor to nitrate removal, but nitrate reduction was not observed in the absence of $\mathrm{Fe}^{0}$. Nitrate removal was also enhanced by augmenting the $\mathrm{Fe}^{0}-\mathrm{H}_{2} \mathrm{O}$ system with $\mathrm{Fe}^{3+}, \mathrm{Cu}^{2+}$, or $\mathrm{Al}^{3+}$ but not $\mathrm{Ca}^{2+}, \mathrm{Mg}^{2+}$, or $\mathrm{Zn}^{2+}$. Our research indicates that a magnetite coating is not a hindrance to nitrate reduction by $\mathrm{Fe}^{0}$, provided sufficient aqueous $\mathrm{Fe}^{2+}$ is present in the system.
\end{abstract}

$\mathrm{T}$ HE WIDESPREAD occurrence of nitrate-contaminated ground water and the expense of mitigating this problem are major concerns for many communities throughout the USA. Although several treatment processes have been developed for nitrate removal, in situ remediation of nitrate-contaminated ground water remains formidable. Recent research indicates many potential uses of zerovalent iron $\left(\mathrm{Fe}^{0}\right)$ in environmental remediation (Stucki, 1988; Matheson and Tratnyek, 1994; Weber, 1996; Scherer et al., 1997, 1998, 2000; Till et al., 1998; Singh et al., 1998). Using $\mathrm{Fe}^{0}$ to remove nitrate from contaminated waters would be an attractive approach provided it is effective at environmentally relevant $\mathrm{pH}$ values.

Past research has demonstrated that the efficiency of nitrate removal by iron metal is largely dependent on pH (Siantar et al., 1995; Singh et al., 1996; Cheng et al., 1997; Hansen and Koch, 1998; Huang et al., 1998; Zawaideh and Zhang, 1998; Alowitz and Scherer, 2002). In acidic solutions $(\mathrm{pH}<2-3)$, nitrate removal in $\mathrm{Fe}^{0}$ $\mathrm{H}_{2} \mathrm{O}$ systems is fast and efficient ( $\geq 95 \%$ ) (Singh et al., 1996; Huang et al., 1998; Zawaideh and Zhang, 1998). However, when solution $\mathrm{pH}$ increases above 5, nitrate removal efficiencies decline and are usually $<50 \%$ (Singh et al., 1996; Cheng et al., 1997; Huang et al., 1998; Zawaideh and Zhang, 1998) unless organic buffers, such as acetic acid, sodium acetate, HEPES [ $N$-(2-hydroxyethyl)piperazine- $N^{\prime}$-(2-ethanesulfonic acid)], or MES [2-( $N$-morpholino)ethanesulfonic acid], are used (Cheng et al., 1997; Zawaideh and Zhang, 1998; Alowitz and

Y. Huang and T. Zhang, Civil Engineering Dep., Univ. of NebraskaLincoln, Omaha Campus, Omaha, NE 68182-0178. P. Shea and S. Comfort, School of Natural Resource Sciences, 309 Biochemistry, University of Nebraska-Lincoln, Lincoln, NE 68583-0728. Received 11 June 2002. *Corresponding author (tzhang@unomaha.edu).

Published in J. Environ. Qual. 32:1306-1315 (2003).
Scherer, 2002). Because near-neutral $\mathrm{pH}$ will be encountered in many soil-water environments, enhancing nitrate reduction by $\mathrm{Fe}^{0}$ without an organic buffer is desirable.

Nitrate reduction by $\mathrm{Fe}^{2+}, \mathrm{Fe}(\mathrm{OH})_{2}$, and hydrous ferrous oxides has been investigated (Sidgwick, 1950; Szabo and Bartha, 1952; Bremner and Shaw, 1955; Brown and Drury, 1967; Bremner and Bundy, 1973; Buresh and Moraghan, 1976; Van Hecke et al., 1990). These studies indicate that at alkaline $\mathrm{pH}, \mathrm{Fe}(\mathrm{OH})_{2}$ rather than free $\mathrm{Fe}^{2+}$ is the species responsible for nitrate reduction to ammonia in the presence of $\mathrm{Cu}^{2+}$, $\mathrm{Ag}^{+}$, or $\mathrm{MgO}$ (Sidgwick, 1950; Szabo and Bartha, 1952; Bremner and Bundy, 1973; Buresh and Moraghan, 1976) and that magnetite is the product of the reaction (Buresh and Moraghan, 1976; Van Hecke et al., 1990). Nitrate reduction has also been associated with the oxidation of green rust [mixed $\mathrm{Fe}(\mathrm{II})-\mathrm{Fe}(\mathrm{III})$ double hydroxides], which can form when $\mathrm{Cl}^{-}, \mathrm{SO}_{4}^{2-}$, or $\mathrm{CO}_{3}^{2-}$ is present during $\mathrm{Fe}^{0}$ corrosion (Hansen and Koch, 1998).

Favorable empirical observations have shifted more attention to mechanisms of contaminant destruction by $\mathrm{Fe}^{0}$. Klausen et al. (1995) proposed that $\mathrm{Fe}^{2+}$ adsorbed on iron oxide surfaces (including magnetite, goethite, and lepidocrocite) or mixed-oxide films plays a key role in the reductive transformation of organic pollutants. Most contaminant destruction is believed to result from interaction with $\mathrm{Fe}^{0}$ or surface $\mathrm{Fe}^{2+}$. Once exposed to an oxidizing environment, however, all $\mathrm{Fe}^{0}$ surfaces become coated with (hydr)oxides that will continue to form and oxidize further with time. To account for this, Scherer et al. (1998) proposed models depicting the iron oxides as passive films, semiconductors, and coordinating surfaces. Surface-coordinated $\mathrm{Fe}^{2+}$ species are essential to the coordinating-surface model and can originate from a variety of sources, such as reductive dissolution of $\mathrm{Fe}^{3+}$ phases (Klausen et al., 1995), "structural" $\mathrm{Fe}^{2+}$ ions within the oxide lattice (Stucki, 1988), or freshly precipitated mixed $\mathrm{Fe}(\mathrm{II})-\mathrm{Fe}(\mathrm{III})$ oxide or hydroxide coatings (magnetite or green rust). According to Stumm (1992), at $\mathrm{pH}$ of $\geq 7.0$, inner-sphere complexation of $\mathrm{Fe}^{2+}$ to metal oxides can create a stronger reductant. Hydrolysis of $\mathrm{Fe}^{2+}$ to $\mathrm{FeOH}^{+}$can also increase reducing power (Schultz and Grundl, 2000). Thus, the nature of the iron (hydr)oxides and their relationships to $\mathrm{Fe}^{0}$ and $\mathrm{Fe}^{2+}$ are critical to understanding mechanisms of nitrate reduction by $\mathrm{Fe}^{0}$.

Our objective was to determine nitrate reduction by $\mathrm{Fe}^{0}$ under anoxic conditions leading to magnetite formation. This study focuses on the oxide coating forming on granular iron and enhanced nitrate removal with iron by adding selected cations in bulk solution at varying $\mathrm{pH}$. We also discuss possible mechanism(s) and the environmental significance of the treatment process. 


\section{MATERIALS AND METHODS}

\section{Chemicals}

Unless otherwise indicated, all aqueous solutions were prepared with ultrapure water (Nanopure Series 550; Barnstead/ Thermolyne Co., Dubuque, IA). The water is deionized water of ultrahigh quality with resistivity up to $18.3 \mathrm{megohm}-\mathrm{cm}$. All commercially available chemicals and minerals were used as received.

The industrial iron powder consisted of filings and shavings that were largely free from visible rust and retained a metallic glaze (US Metals Co., Chicago, IL). The iron particles were approximately $0.5 \mathrm{~mm}$ in diameter, irregular in shape, with a slightly rough surface and a Brunauer-Emmett-Teller (BET) surface area of $0.04 \mathrm{~m}^{2} \mathrm{~g}^{-1}$.

Ferrous iron $\left(\mathrm{Fe}^{2+}\right)$ was prepared from $\mathrm{FeCl}_{2} \cdot 4 \mathrm{H}_{2} \mathrm{O}$ (J.T. Baker Co., Phillipsburg, NJ) and $\mathrm{NaNO}_{3}$ (Baker) was used for preparing the $\mathrm{NO}_{3}^{-}$stock. The selected cations $\left(\mathrm{Fe}^{3+}, \mathrm{Cu}^{2+}\right.$, $\mathrm{Al}^{3+}, \mathrm{Ca}^{2+}, \mathrm{Mg}^{2+}, \mathrm{Zn}^{2+}$ ) were used in the following salt forms: $\mathrm{FeCl}_{3} \cdot 6 \mathrm{H}_{2} \mathrm{O}$ (Fisher Scientific, Pittsburgh, PA), $\mathrm{CuCl}_{2} \cdot 2 \mathrm{H}_{2} \mathrm{O}$ (Fisher), $\mathrm{Al}_{2}\left(\mathrm{SO}_{4}\right)_{3} \cdot 15 \mathrm{H}_{2} \mathrm{O}$ (Fisher), $\mathrm{CaCl}_{2} \cdot 2 \mathrm{H}_{2} \mathrm{O}$ (Mallinckrodt Chemical, Paris, KY), $\mathrm{MgSO}_{4} \cdot 7 \mathrm{H}_{2} \mathrm{O}$ (Baker), and $\mathrm{ZnSO}_{4} \cdot 7 \mathrm{H}_{2} \mathrm{O}$ (EM Science, Darmstadt, Germany). Ferric-ferrous oxide black (Fisher) was the source of magnetite $\left(\mathrm{Fe}_{3} \mathrm{O}_{4}\right)$ powder used.

In some batch tests, the iron powder was precoated with magnetite. To accomplish this, industrial iron powder $(5 \% \mathrm{w} / \mathrm{v})$ was added to a $150-\mathrm{mL}$ serum bottle filled with $100 \mathrm{~mL}$ acidified ( $\mathrm{pH}$ of approximately 2.3) and deoxygenated $\mathrm{NaNO}_{3}$ solution $\left(30 \mathrm{mg} \mathrm{NO}--\mathrm{N} \mathrm{L}^{-1}\right)$. The serum bottle was purged with argon gas for $10 \mathrm{~min}$ and shaken for $10 \mathrm{~h}$ in an opaque box rotating at $30 \mathrm{rpm}$ to form a magnetite coating on the $\mathrm{Fe}^{0}$. We then removed the bulk solution from the bottle, rinsed the iron powder with deoxygenated water, and dried the powder by purging with argon gas.

\section{Experiment Methods}

All batch tests employed 10-mL serum bottles (VWR Int., West Chester, PA) with rubber stoppers as batch reactors.
Initial test conditions are listed in Table 1 (or otherwise specified). In each test, multiple reactors were prepared using the following procedures:

1. Chemicals $\left(\mathrm{NaNO}_{3}\right.$ and $\left.\mathrm{FeCl}_{2} \cdot 4 \mathrm{H}_{2} \mathrm{O}\right)$ were dissolved in ultrapure water and adjusted to the desired $\mathrm{pH}$ using $2 M \mathrm{HCl}$ or $2 M \mathrm{NaOH}$.

2. Solutions were purged with argon gas for $15 \mathrm{~min}$ to eliminate dissolved oxygen and $10 \mathrm{~mL}$ was transferred to reactors containing the solid reactants (iron powder and/or magnetite powder).

3. The reactors were immediately capped with stoppers and the headspace was flushed with argon for $30 \mathrm{~s}$ by inserting (two) needles through the stopper.

4. The reactors were placed in a $30-\times 45-\mathrm{cm}$ box rotating at $30 \mathrm{rpm}$ to provide complete mixing in the dark.

5. At selected times, one reactor was sacrificed for analyses.

In these experiments, only the initial conditions in the reactors were controlled. Ionic strengths ranged from $2.14 \mathrm{mM}$ (Test 1) to $12.8 \mathrm{mM}$ (Test 8). All tests and analyses were conducted at room temperature $\left(24 \pm 1^{\circ} \mathrm{C}\right)$.

\section{Analytical Methods}

Nitrate $\mathrm{N}$, nitrite $\mathrm{N}, \mathrm{pH}$, oxidation-reduction potential (ORP), $\mathrm{Fe}^{2+}$, and $\mathrm{Fe}^{3+}$ were measured at regular intervals. A DX 500 high performance liquid chromatography (HPLC)ion chromatography (IC) system (Dionex Corp., Sunnyvale, $\mathrm{CA}$ ) was used to analyze $\mathrm{NO}_{3}^{-}, \mathrm{NO}_{2}^{-}, \mathrm{NH}_{4}^{+}, \mathrm{Fe}^{2+}, \mathrm{Fe}^{3+}$, and $\mathrm{Cu}^{2+}$. When measuring $\mathrm{NO}_{3}^{-}$and $\mathrm{NO}_{2}^{-}$, a conductivity detector (CD20) and self-regenerating suppressor (SRS) (ASRSULTRA 4-mm) with a 100-mA current were used with an IonPac AG14 4-mm precolumn and separation column. The flow rate of the eluent $\left(2.7 \mathrm{mM} \mathrm{Na} \mathrm{CO}_{3}+1.0 \mathrm{~m} M \mathrm{NaHCO}_{3}\right)$ was $1.2 \mathrm{~mL} \mathrm{~min}{ }^{-1}$. When measuring $\mathrm{Fe}^{2+}, \mathrm{Fe}^{3+}$, and $\mathrm{Cu}^{2+}$, a UV-VIS detector (AD20) was used with an IonPac CG5A 4-mm precolumn and separation column. The flow rate of the eluent (MetPac PDCA; Dionex) was $1.2 \mathrm{~mL} \mathrm{~min}^{-1}$, while the

Table 1. Experimental conditions and results for Batch Tests 1 through $16 . \dagger$

\begin{tabular}{|c|c|c|c|c|c|c|c|c|}
\hline \multirow[b]{2}{*}{ Test } & \multicolumn{6}{|c|}{ Initial conditions } & \multirow[b]{2}{*}{ Result summary } & \multirow[b]{2}{*}{ Final pH } \\
\hline & Iron & $\mathrm{Fe}_{3} \mathrm{O}_{4}$ precoated iron & $\mathrm{Fe}_{3} \mathrm{O}_{4}$ powder & Nitrate $\mathbf{N}$ & $\mathrm{Fe}^{2+}$ & pH & & \\
\hline & $\longrightarrow$ & $\% \mathrm{w} / \mathrm{v}$ & - & $\longrightarrow \mathbf{m g ~ L}$ & $\longrightarrow$ & & & \\
\hline $\mathbf{1}$ & 5 & & & 30 & & 7.1 & Less than $10 \%$ nitrate removed in $48 \mathrm{~h}$. & 9.4 \\
\hline 2 & 5 & & & 30 & & $2.3 \S$ & $\begin{array}{l}\text { Nitrate removal } 98 \% \text { in } 16 \mathrm{~h} .105 \mathrm{mg} \mathrm{Fe} \mathrm{Fe}^{2+} \mathbf{L}^{-1} \\
\text { released immediately and depleted gradually. }\end{array}$ & 8.0 \\
\hline 3 & 5 & & 1 & 30 & & 8.6 & $13 \%$ nitrate removal in $32 \mathrm{~h}$. & 8.7 \\
\hline 4 & 5 & & 1 & 30 & & $2.3 \S$ & Nitrate removal $97 \%$ in $12 \mathrm{~h}$. & 6.8 \\
\hline 5 & & & 1 & 30 & & $2.3 \S$ & No nitrate removal in $60 \mathrm{~h}$. & 2.6 \\
\hline 6 & & & 1 & 30 & & $5.4 \S$ & No nitrate removal in $60 \mathrm{~h}$. & 5.6 \\
\hline 7 & & & 1 & 30 & & 8.59 & No nitrate removal in $60 \mathrm{~h}$. & 8.5 \\
\hline 8 & & & 1 & 30 & 100 & $2.3 \S$ & No nitrate removal in $60 \mathrm{~h}$. & 2.5 \\
\hline 9 & & & 1 & 30 & 100 & 5.2 & $\begin{array}{l}\text { No nitrate removal in } 24 \mathrm{~h} \text {. No adsorption of } \mathrm{Fe}^{2+} \\
\text { on magnetite. }\end{array}$ & $\sim 5.2$ \\
\hline 10 & & & 1 & 30 & 100 & 8.5-9.8 I & $\begin{array}{l}\text { No nitrate removal in } 24 \mathrm{~h} \text {. All dissolved } \mathrm{Fe}^{2+} \text { was } \\
\text { lost instantly due to the initial pH adjustment. }\end{array}$ & $\sim 9.0$ \\
\hline 11 & & 5 & & 30 & & 8.0 & No nitrate removal in $48 \mathrm{~h}$. & 9.4 \\
\hline 12 & & 5 & & 30 & 100 & 5.4 & $\begin{array}{l}\text { Nitrate removal } 97 \% \text { in } 24 \mathrm{~h} \text {. Dissolved } \mathrm{Fe}^{2+} \\
\text { depleted gradually. }\end{array}$ & 8.5 \\
\hline 13 & 5 & & & 30 & 100 & 5.4 & $\begin{array}{l}\text { Nitrate removal } 97 \% \text { in } 24 \mathrm{~h} \text {. Dissolved } \mathrm{Fe}^{2+} \\
\text { depleted gradually. }\end{array}$ & 8.5 \\
\hline 14 & & 5 & & 30 & 100 & 8.5-9.8 I & $\begin{array}{l}10 \% \text { nitrate removal in } 32 \mathrm{~h} \text {. All dissolved } \mathrm{Fe}^{2+} \\
\text { was lost instantly due to the initial pH adjustment. }\end{array}$ & $\sim 9.0$ \\
\hline 15 & & 5 & & & 100 & 5.3 & $\mathrm{Fe}^{2+}$ remains dissolved and stable in $24 \mathrm{~h}$. & $\sim 5.3$ \\
\hline 16 & 5 & & & & 100 & 5.3 & $\begin{array}{l}\mathrm{Fe}^{2+} \text { remains dissolved and stable in } 24 \mathrm{~h} \text {. No black } \\
\text { coating formed. }\end{array}$ & $\sim 5.3$ \\
\hline
\end{tabular}

$\dagger$ All tests were conducted under anoxic conditions, and $\mathrm{FeCl}_{2}$ was the $\mathrm{Fe}^{2+}$ source. † The pH values without footnotes were measured without additional adjustment. $\S$ Initial adjustment with $\mathrm{HCl}$.

II Initial adjustment with $\mathrm{NaOH}$. 
flow rate of the MetPac PAC postcolumn reagent was $0.6 \mathrm{~mL}$ $\min ^{-1}$. When measuring $\mathrm{NH}_{4}^{+}$, a conductivity detector (CD20) and SRS (CSRS-II 4-mm) with a 100-mA current were used. An IonPac CG12A 4- $\times$ 50-mm precolumn and 4- $\times 250-\mathrm{mm}$

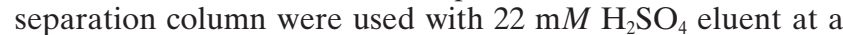
flow rate of $1.0 \mathrm{~mL} \mathrm{~min}^{-1}$. The ORP was measured by a microredox electrode (MI-800-407) together with a reference electrode (MI-401; Microelectrodes, Bedford, NH). A semimicro $\mathrm{pH}$ probe was used for $\mathrm{pH}$ measurements (Thermo Orion, Beverly, MA). Scanning electron microscopy (SEM) (S-3000 $\mathrm{N}$; Hitachi, Tokyo, Japan) was used to discern the features of the source iron and the oxide coating(s) formed under the test conditions.

X-ray diffraction (XRD) was used to determine the iron oxide composition (PAD V model equipped with a peltiercooled, solid-state detector; Scintag, Cupertino, CA). The operating wavelength was $1.5405 \mu \mathrm{m}$ (Cu source). The library used for peak identification was from the JCPDS International Center for Diffraction Data (PCPDFWIN v. 2.01). To form a thin film, the commercial magnetite powder was sprayed onto a piece of glass. To analyze the black precipitate formed in our reaction flasks, the suspension was filtered through a $0.45-\mu \mathrm{m}$ filter paper.

To ascertain the nature of the oxide film forming on the granular iron, a piece of pure iron foil $(25 \times 25 \times 2 \mathrm{~mm}$, 99.9985\% certified; Alfa Aesar, Ward Hill, MA) was used because the granular $\mathrm{Fe}^{0}$ powder was not fine enough to provide a smooth surface for X-ray diffraction analysis. The iron foil was placed in a jar containing $100 \mathrm{~mL}$ of solution with $100 \mathrm{mg} \mathrm{Fe}^{2+} \mathrm{L}^{-1}$ and $30 \mathrm{mg} \mathrm{NO}_{3}^{-}-\mathrm{N} \mathrm{L}^{-1}$ and held under anoxic conditions. After $24 \mathrm{~h}$ of exposure, a black coating covered the iron foil and nitrate loss was similar to that observed when granular $\mathrm{Fe}^{0}$ was used. The coated foil was dried by piercing a needle through the cap and flushing the reactor with ultrapure argon gas (Linweld, Lincoln, NE). Once a positive pressure was created inside the reactor, a second needle was pierced through the cap of the reactor. The second needle was used to decant the liquid from the reactor. The oxide-coated iron foil was then rinsed by introducing deoxygenated water into the reactor via the second needle while argon gas was still flushing via the first needle. After the rinse, the second needle served as a vent for flushing with argon gas to dry the sample (about $1 \mathrm{~h}$ ). The dry sample was preserved against oxidation under argon until analysis.

\section{RESULTS Effects of Initial pH}

When solution $\mathrm{pH}$ was unbuffered $(\mathrm{pH} 7.1$; Test 1 in Table 1), use of $\mathrm{Fe}^{0}$ alone resulted in $<10 \% \mathrm{NO}_{3}^{-}-\mathrm{N}$ removal within $24 \mathrm{~h}$. The bulk solution $\mathrm{pH}$ increased from 7.1 to 9.4 during the reaction and no $\mathrm{Fe}^{2+}$ or $\mathrm{Fe}^{3+}$ was detected in solution (Fig. 1a). After $24 \mathrm{~h}$, the iron surface was coated with a black iron oxide and no additional nitrate removal was observed.

When the initial $\mathrm{pH}$ was lowered to 2.3 (Test 2 in Table 1), nitrate reduction occurred in three stages (Fig. 1b,c). In Stage 1 (the first $30 \mathrm{~min}$ ), nitrate concentration rapidly decreased $\left(>5 \mathrm{mg} \mathrm{NO}_{3}^{-}-\mathrm{N} \mathrm{L}^{-1}\right.$ removed within $0.5 \mathrm{~h}$ ) while the $\mathrm{pH}$ sharply increased from 2.3 to 4.8 as a result of the reaction between $\mathrm{Fe}^{0}$ and $\mathrm{H}^{+}$ $\left(\mathrm{Fe}^{0}+2 \mathrm{H}^{+} \rightarrow \mathrm{Fe}^{2+}+\mathrm{H}_{2} \uparrow\right)$. Small bubbles, presumably $\mathrm{H}_{2}$, were observed on the iron surface and about $105 \mathrm{mg}$ $\mathrm{Fe}^{2+} \mathrm{L}^{-1}$ was detected in solution. Stage 2 was character- ized by a slower rate of nitrate removal. During this stage $(0.5-10 \mathrm{~h})$, the $\mathrm{pH}$ increased from 4.8 to 6.2 and corresponded to a decrease in $\mathrm{Fe}^{2+}$ (105 to about $75 \mathrm{mg}$ $\mathrm{L}^{-1}$ ). A black coating on the $\mathrm{Fe}^{0}$ surface was visible at about $5 \mathrm{~h}$. A black precipitate, arising from the solution phase or detachment of the black coating from the $\mathrm{Fe}^{0}$ surface, became visible at about $10 \mathrm{~h}$. The X-ray diffraction analysis (see below) identified both the black precipitate and the black coating as magnetite $\left(\mathrm{Fe}_{3} \mathrm{O}_{4}\right)$. The appearance of the black precipitate in solution denoted the beginning of Stage 3, which was characterized by rapid loss of nitrate from solution and a concurrent disappearance of aqueous $\mathrm{Fe}^{2+}$. The remaining nitrate (approximately 67\%) was removed within $20 \mathrm{~h}$ at nearneutral $\mathrm{pH}$ during Stage 3. During the entire test, $\mathrm{NH}_{4}^{+}$was the only nitrogen product detected and it resulted in a near complete $(100 \%)$ nitrogen mass balance (Fig. 1b).

\section{Screening Tests}

Stage 3 indicated that nitrate could be rapidly reduced at neutral $\mathrm{pH}$ but not until the iron became coated with magnetite and $\mathrm{Fe}^{2+}$ was present in the bulk solution. In addition to $\mathrm{pH}$, three test parameters were varied during a series of 16 batch experiments (hereinafter referred to as Tests 1-16). In these tests, no additional chemicals were added to control the ionic strength in each batch reactor. The initial ionic strengths, calculated based on the test conditions shown in Table 1, were $2.14 \mathrm{~m} M$ for Tests $1,3,6,7$, and 11; $7.14 \mathrm{mM}$ for Tests 2, 4, and 5; $5.4 \mathrm{~m} M$ for Tests 15 and 16; $7.54 \mathrm{mM}$ for Tests 9,10 , and 12 through 14; and $12.54 \mathrm{~m} M$ for Test 8 . These tests were designed to determine the effects of the magnetite coating on the $\mathrm{Fe}^{0}$ surface, the addition of magnetite as a separate phase in the batch reactor, and the presence of aqueous $\mathrm{Fe}^{2+}$ during corrosion of the $\mathrm{Fe}^{0}$. To determine whether $\mathrm{Fe}^{2+}$ in solution or $\mathrm{Fe}^{2+}$ sorbed onto magnetite would reduce nitrate in a magnetite-nitrate$\mathrm{Fe}^{2+}$-water system, tests with batch reactors containing $1 \%(\mathrm{w} / \mathrm{v})$ commercial magnetite, approximately $90 \mathrm{mg}$ $\mathrm{Fe}^{2+} \mathrm{L}^{-1}$, and $30 \mathrm{mg} \mathrm{NO}_{3}^{-}-\mathrm{N} \mathrm{L}^{-1}$ were conducted under anoxic conditions and a range of $\mathrm{pH}$ values (2-10) that crossed the zero point of charge (ZPC) of the iron oxides (see Table 2). Although green rust can facilitate rapid nitrate removal at neutral $\mathrm{pH}$ (Hansen and Koch, 1998), green rust was not visually observed before or after the formation of the black precipitate in these experiments.

When the initial $\mathrm{pH}$ was 8.6 (Test 3 in Table 1), adding magnetite did not enhance nitrate reduction. When the $\mathrm{pH}$ was lowered to 2.3 and magnetite was present (Test 4), nitrate was completely removed from the reactor within $12 \mathrm{~h}$ (Fig. 1d). The removal rate was similar to that observed in Stage 3 of Test 2 (Fig. 1b). Moreover, addition of the magnetite eliminated the stage with moderate nitrate removal (Stage 2, Fig. 1b).

No nitrate removal was detected in the absence of $\mathrm{Fe}^{0}$ (Tests 5-10 in Tables 1 and 2), indicating that neither magnetite (Tests 5-7) nor magnetite combined with $\mathrm{Fe}^{2+}$ (Tests 8-10 in Tables 1 and 2) was responsible for the rapid loss of nitrate from solution during Stage 3 

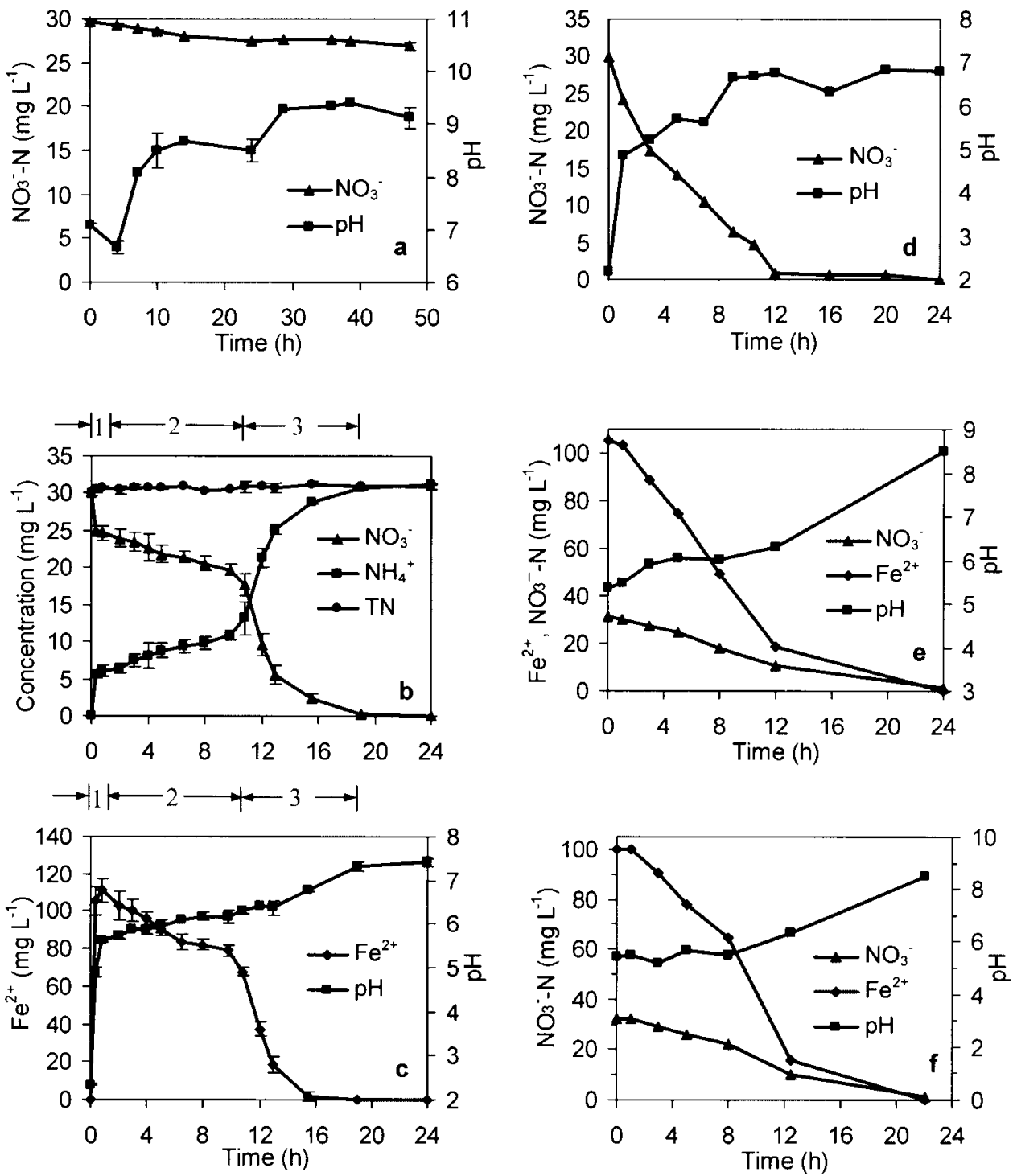

Fig. 1. Results of batch tests under differing experimental conditions (defined in Table 1). $(a)$ Test 1; $(b, c)$ Test 2 (note that nitrate reduction occurred in three stages, $\left.\mathrm{TN}=\mathrm{NH}_{4}^{+}+\mathrm{NO}_{3}^{-}\right) ;(d)$ Test 4; $(e)$ Test 12; and $(f)$ Test 13. Values and error bars in $(a),(b)$, and $(c)$ represent the average and plus or minus one standard deviation, respectively, from three replicate runs.

(of Test 2). When $\mathrm{Fe}^{0}$ was precoated with magnetite without an initial $\mathrm{pH}$ adjustment, no nitrate removal was observed (Test 11), indicating that the black coating on the surface of granular $\mathrm{Fe}^{0}$ was not directly responsible for rapid nitrate reduction. When magnetite-coated $\mathrm{Fe}^{0}$ (Test 12) or noncoated $\mathrm{Fe}^{0}$ (Test 13) was used with $\mathrm{Fe}^{2+}$ at an initial $\mathrm{pH}$ of 5.4, almost all of the initial $30 \mathrm{mg}$ $\mathrm{L}^{-1}$ nitrate was removed within $24 \mathrm{~h}$ and accompanied by the formation of a black precipitate. Moreover, the noncoated $\mathrm{Fe}^{0}$ (Test 13) was covered with a black oxide within the first $2 \mathrm{~h}$. Results from the magnetite-coated and noncoated $\mathrm{Fe}^{0}$ were nearly identical (Fig. 1e,f), indicating that the magnetite coating was not a hindrance to nitrate removal as long as $\mathrm{Fe}^{2+}$ was available. This was further supported by Test 14 , in which $100 \mathrm{mg} \mathrm{Fe}{ }^{2+}$ $\mathrm{L}^{-1}$ was added to magnetite-coated $\mathrm{Fe}^{0}$ and then the $\mathrm{pH}$ was raised to $\geq 8.5$ to precipitate the aqueous $\mathrm{Fe}^{2+}$ as $\mathrm{Fe}(\mathrm{OH})_{2}$. Results indicated no dissolved $\mathrm{Fe}^{2+}$ in solution and only $10 \%$ nitrate removal in $32 \mathrm{~h}$.
Results from the control tests (no $\mathrm{NO}_{3}^{-}$added) demonstrated the important role nitrate plays as an electron acceptor in the anoxic $\mathrm{Fe}^{0}-\mathrm{H}_{2} \mathrm{O}$ system. In these tests, the added $\mathrm{Fe}^{2+}$ remained dissolved and stable for a comparable test period with no $\mathrm{pH}$ change (Test 15) and no black oxide coating was observed on the bare $\mathrm{Fe}^{0}$ surface (Test 16). This is in sharp contrast to the results of Tests 12 and 13, where adding nitrate resulted in aqueous $\mathrm{Fe}^{2+}$ disappearance from solution and formation of a black oxide coating.

\section{X-Ray Diffraction and Scanning Electron Microscopy Analysis}

The X-ray diffraction analysis of the commercial magnetite powder (Fig. 2a) matched the magnetite spectrum from the X-ray diffraction library (peaks at 18, 30, 35.5, $37,43,53,57,62.5$, and 74 degree in $2 \theta$, Cu source). In addition to the magnetite peaks, the diffractograms from 
Table 2. Effect of $\mathrm{Fe}^{2+}$ on nitrate removal in magnetite-nitratewater batch system. $\dagger$

\begin{tabular}{|c|c|c|c|c|c|c|}
\hline \multirow[b]{2}{*}{ Reactor } & \multicolumn{3}{|c|}{ After pH adjustment } & \multicolumn{3}{|c|}{ After 32 h running } \\
\hline & pH & Nitrate $\mathbf{N}$ & $\mathrm{Fe}^{2+}$ & pH & Nitrate $\mathbf{N}$ & $\mathrm{Fe}^{2+}$ \\
\hline & & \multicolumn{2}{|c|}{$\longrightarrow \mathrm{mg} \mathrm{L}^{-1}$} & & \multicolumn{2}{|c|}{$\mathrm{mg} \mathrm{L}^{-1}$} \\
\hline R1 & 2.25 & 30.00 & 90.39 & 2.29 & 30.97 & 94. \\
\hline $\mathbf{R 2}$ & 2.90 & 29.33 & 91.50 & 2.90 & 30.87 & 94.77 \\
\hline $\mathbf{R 3}$ & 3.67 & 28.87 & 90.75 & 3.85 & 30.46 & 91.05 \\
\hline R4 & 4.98 & 28.91 & 87.24 & 4.01 & 30.53 & 81.87 \\
\hline R5 & 5.38 & 29.43 & 76.32 & 3.99 & 30.38 & 69.06 \\
\hline R6 & 5.93 & 29.37 & 63.75 & 4.20 & 30.37 & 59.25 \\
\hline R7 & 6.15 & 29.31 & 50.79 & 4.50 & 30.12 & 45.15 \\
\hline R8 & 6.74 & 29.97 & 27.99 & 4.85 & 30.58 & 22.11 \\
\hline R9 & 7.11 & 29.27 & 2.55 & 6.60 & 30.48 & 1.89 \\
\hline R10 & 9.00 & 29.11 & 0.00 & 7.08 & 30.12 & 0.00 \\
\hline R11 & 10.56 & 29.41 & 0.00 & 9.70 & 30.45 & 0.00 \\
\hline
\end{tabular}

$\dagger$ No nitrate removal was detected in $\mathbf{3 2} \mathbf{~}$ in the batch reactors initially containing $1 \%(\mathrm{w} / \mathrm{v})$ magnetite, approximately $90 \mathrm{mg} \mathrm{Fe} \mathrm{e}^{2+} \mathrm{L}^{-1}$, and 30 mg NO${ }_{3}^{-}-\mathrm{N} \mathrm{L}^{-1}$ under anoxic conditions at $\mathrm{pH} 2-10$. Initial $\mathrm{pH}$ was adjusted with $\mathrm{HCl}$ or $\mathrm{NaOH}$. The $\mathrm{Fe}^{2+}$ largely remains stable after initial pH adjustment. The pH edge of $\mathrm{Fe}^{2+}$ precipitation was approximately 6.5.

the black oxide coating (Fig. 2b) and the black precipitate (Fig. 2c) included peaks at 44.6 and 65 degrees, which were identified by the library as metallic iron. The black precipitate also contains some background peaks (e.g., peak at 52 degrees) belonging to the filter paper (Fig. 2c). A comparison of all diffractograms (Fig. 2) provides evidence that both the black precipitate and the black coating were magnetite. While the commercial magnetite powder, the black coating, and magnetite precipitate appeared equivalent in composition and morphology, some differences are likely (Sidhu et al., 1978). The black coating that initially formed on $\mathrm{Fe}^{0}$ (Test 13) may be an amorphous (hydr)oxide, which transforms to magnetite in the presence of $\mathrm{Fe}(\mathrm{II})$ at alkaline pH (Tamaura et al., 1983).
The morphological features of the black coating and black precipitate were evaluated by scanning electron microscopy (Fig. 3). The similarity between the black coating and black precipitate suggests that the black precipitate originated from the black coating or precipitated directly from solution.

\section{Ferrous Iron Consumption and Nitrate Reduction to Ammonium}

Because bathing the corroding $\mathrm{Fe}^{0}$ in a $\mathrm{Fe}^{2+}$ solution facilitated nitrate reduction and its loss paralleled loss of nitrate (Fig. 1b,c), we determined the relationship between $\mathrm{Fe}^{2+}$ loss and nitrate reduction. Batch reactors in these experiments contained $100 \mathrm{mg} \mathrm{NO}_{3}^{-}-\mathrm{N} \mathrm{L}^{-1}$ (as opposed to $30 \mathrm{mg} \mathrm{L}^{-1}$ ), $100 \mathrm{mg} \mathrm{Fe}^{2+} \mathrm{L}^{-1}$, and 5\% (w/v) magnetite-coated $\mathrm{Fe}^{0}$ and were agitated without additional $\mathrm{pH}$ control (initial $\mathrm{pH}=5.4$ ). Within $19 \mathrm{~h}, 35 \mathrm{mg}$ $\mathrm{NO}_{3}^{-}-\mathrm{N} \mathrm{L}^{-1}$ was transformed to $\mathrm{NH}_{4}^{+}-\mathrm{N}$ (approximately $35 \mathrm{mg} \mathrm{L}^{-1}$ ) and all of the initial $100 \mathrm{mg} \mathrm{Fe}^{2+} \mathrm{L}^{-1}$ was consumed. Once all $\mathrm{Fe}^{2+}$ was lost from solution, nitrate removal stopped (Curves 1 and $1^{\prime}$ in Fig. 4). However, when a second dose of $100 \mathrm{mg} \mathrm{Fe}{ }^{2+} \mathrm{L}^{-1}$ was added at $19 \mathrm{~h}$, an additional $35 \mathrm{mg} \mathrm{NO}_{3}^{-}-\mathrm{N} \mathrm{L}^{-1}$ was transformed to $\mathrm{NH}_{4}^{+}-\mathrm{N}$ by $42 \mathrm{~h}$ (Curves 2 and $2^{\prime}$ in Fig. 4). Based on the molar ratio $(35 / 14: 100 / 56=1: 0.72)$, transforming 1 mol $\mathrm{NO}_{3}^{-}-\mathrm{N}$ to $\mathrm{NH}_{4}^{+}-\mathrm{N}$ under the test conditions would consume $0.72 \mathrm{~mol} \mathrm{Fe}^{2+}$.

To further explore the relationship between $\mathrm{Fe}^{2+}$ and $\mathrm{NO}_{3}^{-}$removal, a series of batch tests were conducted. The initial conditions were $5 \%$ magnetite-coated $\mathrm{Fe}^{0}+$ $7.14 \mathrm{~m} M \mathrm{NO}_{3}^{-}-\mathrm{N}\left(100 \mathrm{mg} \mathrm{NO}--\mathrm{N} \mathrm{L}^{-1}\right)+0,0.9,1.8$ 2.7 , or $3.6 \mathrm{mM} \mathrm{Fe} \mathrm{Fe}^{2+}\left(0,50,100,150\right.$, or $\left.200 \mathrm{mg} \mathrm{L}^{-1}\right)$ without $\mathrm{pH}$ control (initial $\mathrm{pH}=5.0-5.5$ ). As shown

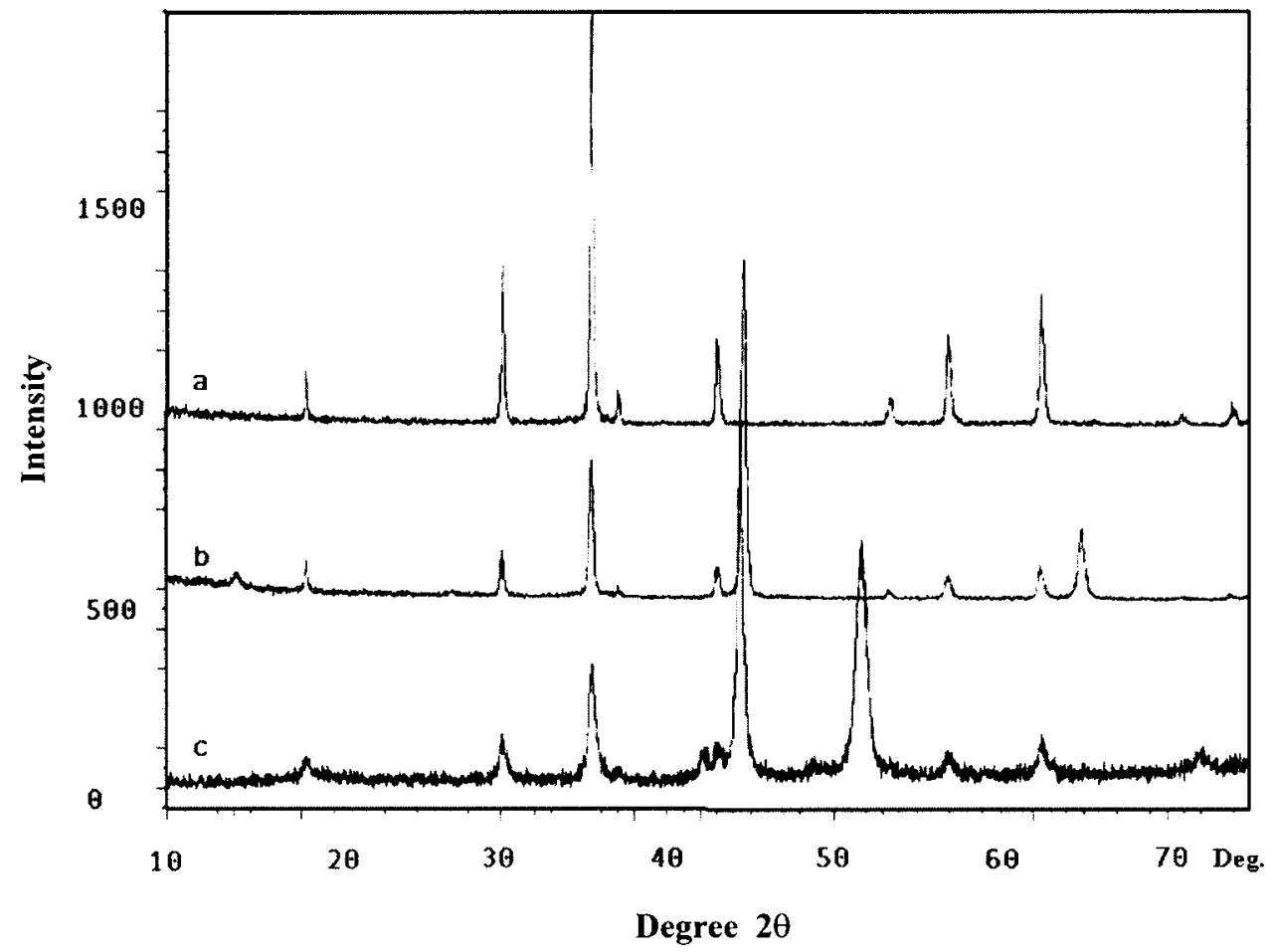

Fig. 2. X-ray diffraction spectra analyses indicate that the black oxide coating and black precipitate generated from nitrate reduction by $\mathrm{Fe}^{0}$ under the anoxic condition are magnetite. (a) Commercial magnetite powder; $(b)$ black coating on $\mathrm{Fe}^{0}$; and $(c)$ black precipitate on filter paper. 
in Fig. 5, results indicated that nitrate removals were proportional to the initial concentration of aqueous $\mathrm{Fe}^{2+}$. Based on these results, $0.75 \mathrm{~m} M \mathrm{Fe}^{2+}$ corresponded to $1 \mathrm{mM} \mathrm{NO} \mathrm{NO}_{3}^{-}-\mathrm{N}$ removed, indicated by the slope $(1 / 0.75)$ of the line $\left[\mathrm{Fe}^{2+}\right.$ added $=0.75\left(\mathrm{NO}_{3}^{-}-\mathrm{N}\right.$ removed) $\left.-0.22 ; R^{2}=0.99\right]$ in Fig. 5b. The new value (0.75 $\mathrm{mM} \mathrm{Fe} \mathrm{Fe}^{2+}$ for $1 \mathrm{~m} M \mathrm{NO}_{3}^{-}-\mathrm{N}$ transformation) can be considered refined from the preliminary result (approximately $0.72 \mathrm{~m} M \mathrm{Fe}^{2+}$ for $1 \mathrm{~m} M \mathrm{NO}_{3}^{-}-\mathrm{N}$ ) based on Fig. 4.

\section{Cations}

Based on results obtained with $\mathrm{Fe}^{2+}$, we speculated that other cations may also accelerate nitrate reduction and selected $\mathrm{Fe}^{3+}, \mathrm{Cu}^{2+}, \mathrm{Al}^{3+}, \mathrm{Ca}^{2+}, \mathrm{Mg}^{2+}$, and $\mathrm{Zn}^{2+}$ for further testing. Experiments were conducted using magnetite-coated $\mathrm{Fe}^{0}$ with no $\mathrm{pH}$ adjustment. To be consistent, $1.8 \mathrm{~m} M$ selected cation was used in each of these tests. The initial $\mathrm{pH}$ differed slightly from that in the tests with $\mathrm{Fe}^{2+}$ due to the different hydrolysis reactions associated with the selected cations. The initial ionic strengths were $17.94 \mathrm{~m} M$ in the tests with $\mathrm{Fe}^{3+}$, $12.54 \mathrm{~m} M$ with $\mathrm{Cu}^{2+}$ and $\mathrm{Ca}^{2+}, 20.64 \mathrm{~m} M$ with $\mathrm{Al}^{3+}$, and $14.34 \mathrm{~m} M$ with $\mathrm{Mg}^{2+}$ and $\mathrm{Zn}^{2+}$. Results indicated that $\mathrm{Fe}^{3+}, \mathrm{Cu}^{2+}$, and $\mathrm{Al}^{3+}$ accelerated nitrate reduction by precoated iron at near-neutral $\mathrm{pH}$ with a similar $\mathrm{pH}$ change (e.g., for $\mathrm{Cu}^{2+}$, $\mathrm{pH}$ changed from 4.9 to 9.1) as observed in tests with $\mathrm{Fe}^{2+}$ (below), while $\mathrm{Ca}^{2+}, \mathrm{Mg}^{2+}$, and $\mathrm{Zn}^{2+}$ had no significant effect $(<5 \%$ nitrate removed, $\mathrm{pH}$ increased from $<6$ to $9-10)$.

When $100 \mathrm{mg} \mathrm{Fe}^{3+} \mathrm{L}^{-1}(1.8 \mathrm{mM})$ and $100 \mathrm{mg} \mathrm{NO}_{3}^{-}$ $-\mathrm{N} \mathrm{L}^{-1}$ were added to the $\mathrm{Fe}^{0}-\mathrm{H}_{2} \mathrm{O}$, almost all of the $\mathrm{Fe}^{3+}$ disappeared within the first $30 \mathrm{~min}$ while an equivalent charge balance of $\mathrm{Fe}^{2+}\left(150 \mathrm{mg} \mathrm{L}^{-1}\right)$ was detected in solution (Fig. 6a). On release of $\mathrm{Fe}^{2+}$ (following loss of $\mathrm{Fe}^{3+}$ ), observations were similar to previous tests (rapid nitrate reduction, $\mathrm{Fe}^{2+}$ depletion, gradual $\mathrm{pH}$ increase, and formation of a black precipitate). When $\mathrm{Fe}^{2+}$ became depleted, nitrate reduction had plateaued, with about $55 \mathrm{mg} \mathrm{NO}_{3}^{-}-\mathrm{N} \mathrm{L}^{-1}$ removed. When nitrate was omitted in a control test, adding $100 \mathrm{mg} \mathrm{Fe}^{3+} \mathrm{L}^{-1}$ to the $\mathrm{Fe}^{0}-\mathrm{H}_{2} \mathrm{O}$ system still resulted in release of $150 \mathrm{mg} \mathrm{Fe}{ }^{2+}$ $\mathrm{L}^{-1}$ into solution, but the $\mathrm{Fe}^{2+}$ concentration remained stable throughout the same test period. By using uncoated $\mathrm{Fe}^{0}$ instead of magnetite-coated $\mathrm{Fe}^{0}$, almost identical results were obtained (data not shown). When $114 \mathrm{mg} \mathrm{Cu}{ }^{2+} \mathrm{L}^{-1}(1.8 \mathrm{mM})$ was used in lieu of $\mathrm{Fe}^{3+}$, instant release of $100 \mathrm{mg} \mathrm{Fe}^{2+} \mathrm{L}^{-1}(1.8 \mathrm{mM})$ was observed (Fig. 6b) and metallic $\mathrm{Cu}\left(\mathrm{Cu}^{0}\right)$ was observed in both the magnetite film and the black precipitate. Approximately $35 \mathrm{mg} \mathrm{NO}_{3}^{-}-\mathrm{N} \mathrm{L}^{-1}$ was rapidly reduced and paralleled $\mathrm{Fe}^{2+}$ depletion and black precipitate formation. Without nitrate addition, the released $\mathrm{Fe}^{2+}$ remained constant $\left(100 \mathrm{mg} \mathrm{L}^{-1}\right)$ throughout the test (Fig. 6b). When $48.6 \mathrm{mg} \mathrm{Al}^{3+} \mathrm{L}^{-1}(1.8 \mathrm{mM})$ was used in a similar experiment, $\mathrm{Al}^{3+}$ addition resulted in the release of $150 \mathrm{mg} \mathrm{Fe}{ }^{2+} \mathrm{L}^{-1}(2.7 \mathrm{mM})$ (similar to the test with $\mathrm{Fe}^{3+}$ ), and approximately $50 \mathrm{mg} \mathrm{NO}_{3}^{-}-\mathrm{N} \mathrm{L}^{-1}$ was removed (data not shown). a

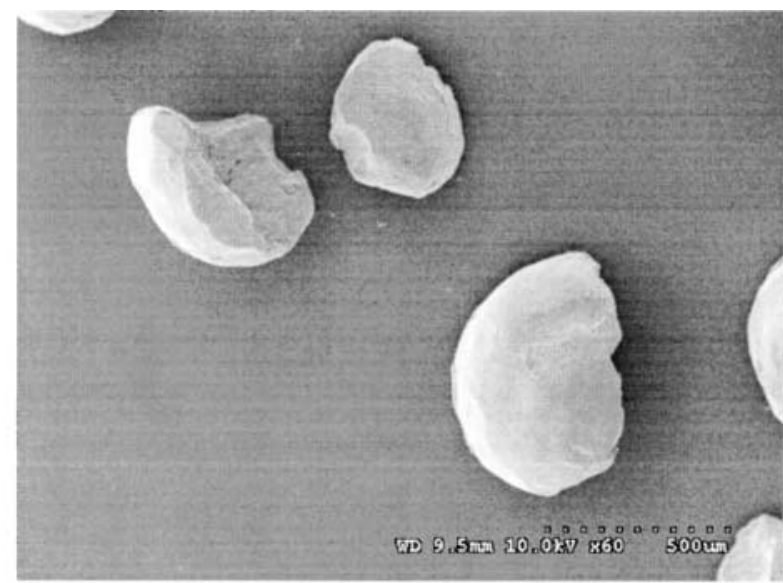

b

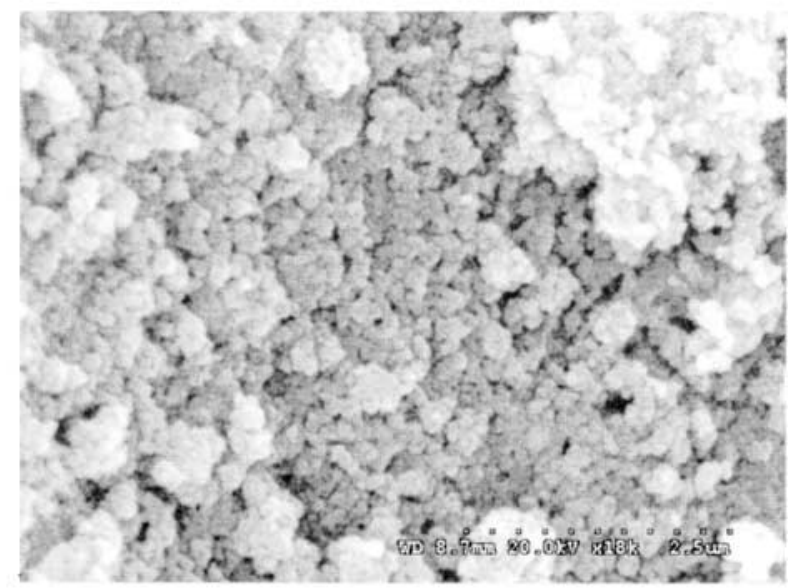

c

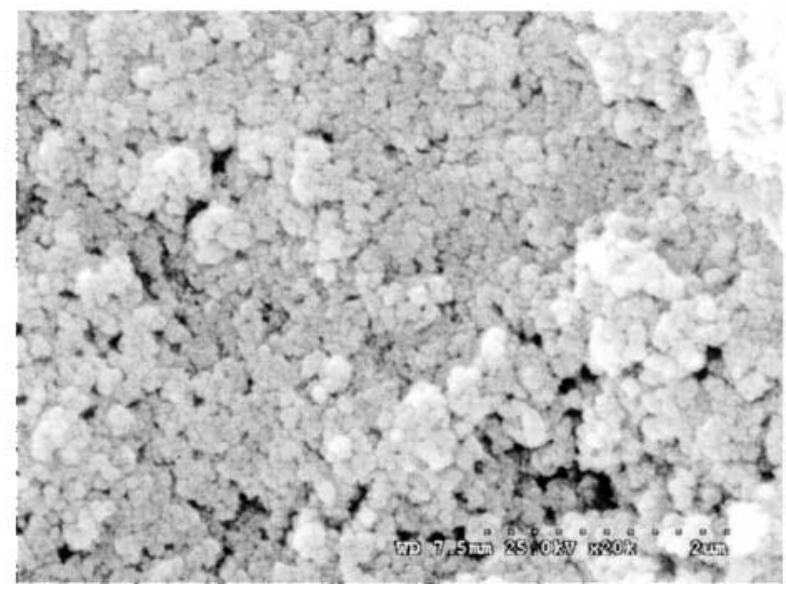

Fig. 3. Scanning electron microscope (SEM) image of $(a)$ granular $\mathrm{Fe}^{0}$ before use, bare surface $(\times 60)$; $(b)$ granular iron coated with magnetite after $20 \mathrm{~h}$ in the reactor with the initial conditions of Test $12(\times 18 \mathrm{k})$; and $(c)$ black precipitate on a filter paper, obtained after $10 \mathrm{~h}$ from the reactor with the initial conditions of Test $13(\times 20 k)$.

\section{Chloride}

Chloride enhances iron pitting and corrosion and has been suggested as a possible mechanism for contaminant reduction (Scherer et al., 1998, 2000). In tests with $\mathrm{Fe}^{2+}, \mathrm{Fe}^{3+}, \mathrm{Cu}^{2+}$, and $\mathrm{Ca}^{2+}$, chloride salts were used, and therefore $\mathrm{Cl}^{-}$was the major anion in the system. No change in $\mathrm{Cl}^{-}$concentration was detected in any of 


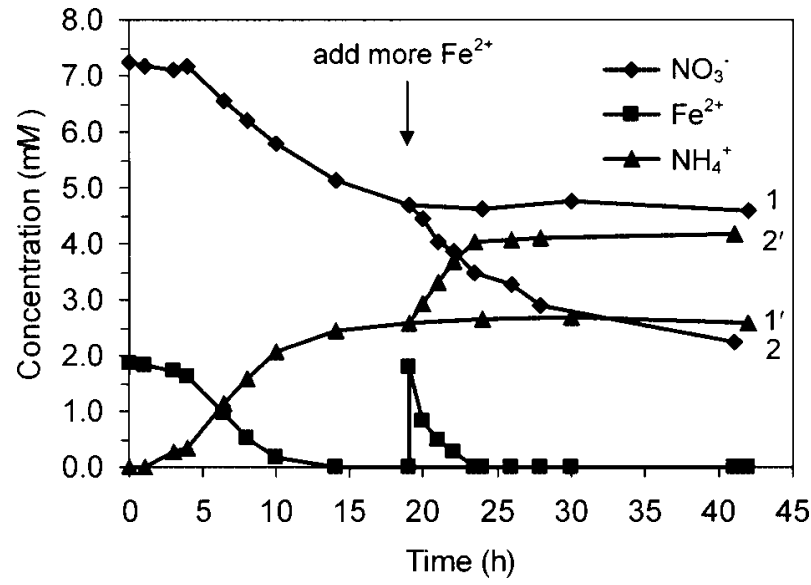

Fig. 4. Results of the stoichiometric test. Transforming $1 \mathrm{~mol}$ of $\mathrm{NO}_{3}^{-}-\mathrm{N}$ to $\mathrm{NH}_{4}^{+}-\mathrm{N}$ consumed $0.75 \mathrm{~mol}$ of aqueous $\mathrm{Fe}^{2+}$. Results are averages of duplicates.

the tests. These tests indicate that $\mathrm{Cl}^{-}$is not a major contributing factor under the conditions of our experiments. Results using 5\% magnetite-coated $\mathrm{Fe}^{0}+1000 \mathrm{mg}$ $\mathrm{Cl}^{-} \mathrm{L}^{-1}$ (as $\mathrm{NaCl}$ ) $+30 \mathrm{mg} \mathrm{NO}-\mathrm{N} \mathrm{L} \mathrm{L}_{3}^{-1}$ without $\mathrm{pH}$ control also did not enhance nitrate reduction $(<10 \%$ nitrate removed in $72 \mathrm{~h}$ ).

\section{DISCUSSION}

The results of this study indicate that in anoxic $\mathrm{Fe}^{0}-$ $\mathrm{H}_{2} \mathrm{O}$ systems, nitrate is removed very rapidly at low $\mathrm{pH}$
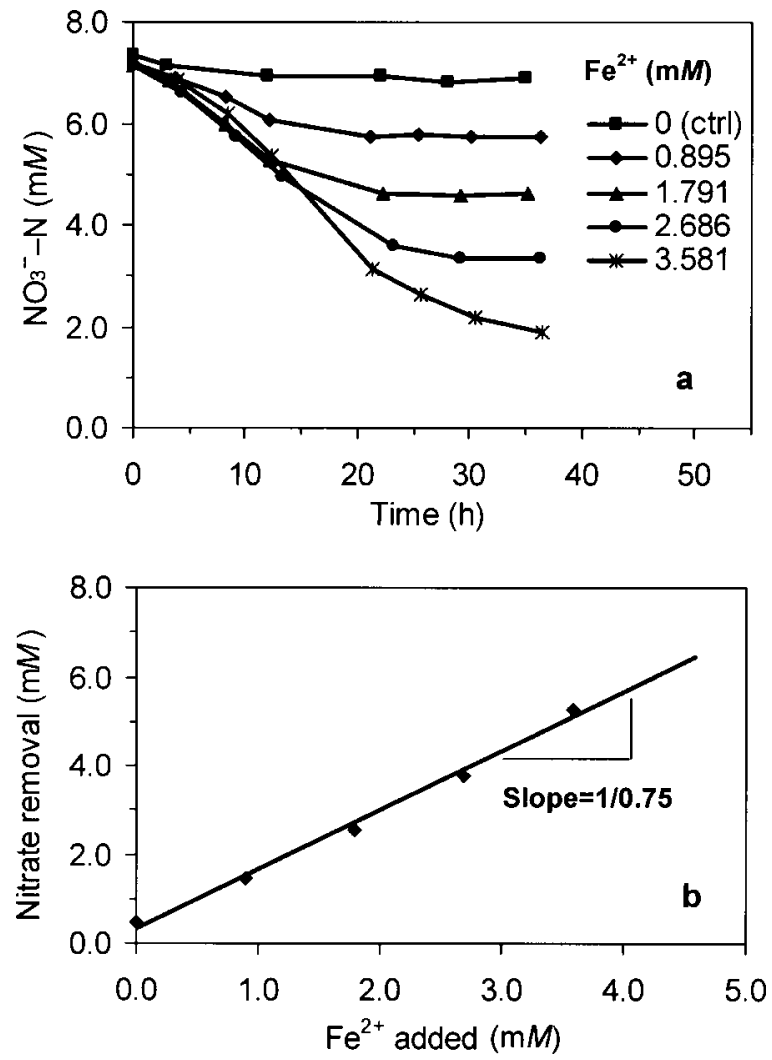

Fig. 5. Series of tests with various initial $\mathrm{Fe}^{2+}$ concentrations $(0-3.6$ $\mathrm{m} M$ or $0-200 \mathrm{mg} \mathrm{L}^{-1}$ ) show the stoichiometry between nitrate reduction and $\mathrm{Fe}^{2+}$ depletion in the anoxic magnetite-coated $\mathrm{Fe}^{0}-$ nitrate- $\mathrm{H}_{2} \mathrm{O}$ system.
(2-4), while oxide formation at higher $\mathrm{pH}$ will potentially halt the transformation of nitrate. Under our experimental conditions, magnetite (as a surface oxide or precipitate) was a product of nitrate reduction because it was not formed in the absence of nitrate.

At neutral $\mathrm{pH}$, we demonstrated that neither magnetite-coated $\mathrm{Fe}^{0}$ nor magnetite used alone or in combination with $\mathrm{Fe}^{2+}$ was directly responsible for enhanced nitrate removal. However, if $\mathrm{Fe}^{2+}$ or other selected cations $\left(\mathrm{Fe}^{3+}, \mathrm{Cu}^{2+}\right.$, or $\left.\mathrm{Al}^{3+}\right)$ coexisted in the bulk solution with $\mathrm{Fe}^{0}$ or magnetite-coated $\mathrm{Fe}^{0}$, efficient reduction of nitrate to ammonium occurred.

We also demonstrated that reducing $1 \mathrm{~mol}$ of $\mathrm{NO}_{3}^{-}$ $-\mathrm{N}$ to $\mathrm{NH}_{4}^{+}-\mathrm{N}$ in the $\mathrm{Fe}^{0}-\mathrm{H}_{2} \mathrm{O}$ system at near-neutral $\mathrm{pH}$ requires $0.75 \mathrm{~mol}$ of $\mathrm{Fe}^{2+}$. Based on this stoichiometric coefficient (0.75) and some additional assumptions, we describe the redox reaction occurring in our systems as follows. In our calculations, we have assumed that (i) $\mathrm{NH}_{4}^{+}$is produced from nitrate, (ii) both $\mathrm{Fe}^{0}$ and $\mathrm{Fe}^{2+}$ can serve as electron donors, and (iii) the primary oxidation product of $\mathrm{Fe}^{0}$ and $\mathrm{Fe}^{2+}$ is $\mathrm{Fe}_{3} \mathrm{O}_{4}$ at a $\mathrm{Fe}$ (III) to $\mathrm{Fe}(\mathrm{II})$ ratio of $2: 1$. We also recognized that the conversion of one mole of $\mathrm{NO}_{3}^{-}-\mathrm{N}$ to $\mathrm{NH}_{4}^{+}-\mathrm{N}$ will produce $X$ moles of $\mathrm{Fe}_{3} \mathrm{O}_{4}$. Each $X$ moles of $\mathrm{Fe}_{3} \mathrm{O}_{4}$ contains $3 X$ moles of iron, of which $2 X$ moles will be $\mathrm{Fe}(\mathrm{III})$ and $1 X$ moles will be $\mathrm{Fe}(\mathrm{II})$. For the $\mathrm{Fe}(\mathrm{II})$, our experiments support that 0.75 (stoichiometric coefficient) will come from the aqueous $\mathrm{Fe}^{2+}$ bathing the corroding iron and the rest from the $\mathrm{Fe}^{0}$. Therefore, $3 X-0.75 \mathrm{~mol}$ of $\mathrm{Fe}^{0}$
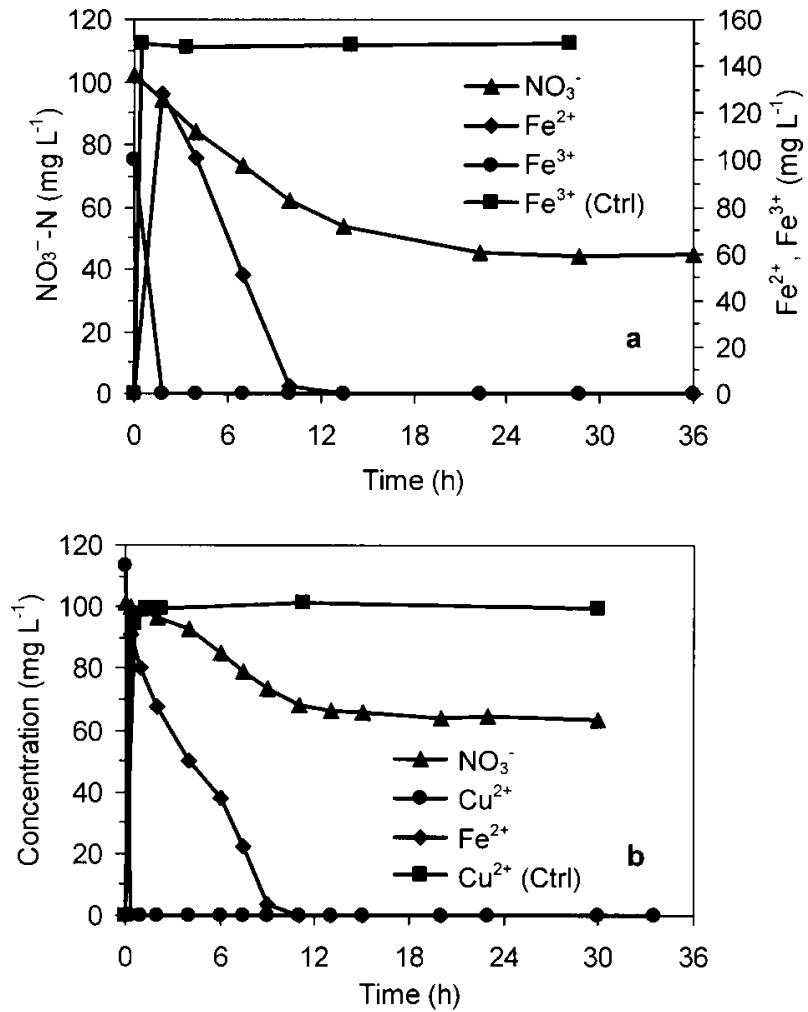

Fig. 6. Effect of $\mathrm{Fe}^{3+}$ or $\mathrm{Cu}^{2+}$ addition on nitrate removal. Initial conditions: $5 \%$ precoated iron $+30 \mathrm{mg} \mathrm{NO}-\mathrm{N} \mathrm{L}^{-1}+(a) 100 \mathrm{mg}$ $\mathrm{Fe}^{3+} \mathrm{L}^{-1}\left(\mathrm{FeCl}_{3}\right)$ or (b) $115 \mathrm{mg} \mathrm{Cu}{ }^{2+} \mathrm{L}^{-1}\left(\mathrm{CuCl}_{2}\right)$, without initial pH adjustment. 
will be oxidized. The oxidation of $\mathrm{Fe}^{0}$ will yield both $\mathrm{Fe}(\mathrm{II})$ and $\mathrm{Fe}(\mathrm{III})$ and eight electrons are required to convert nitrate to ammonium. Consequently, $3(2 X)+$ $2(X-0.75)=8 \mathrm{~mol}$ electrons and $X=1.19$. Correspondingly, $2.38 \mathrm{~mol} \mathrm{Fe}{ }^{0}$ will become $\mathrm{Fe}(\mathrm{III})$, while 0.44 (i.e., 1.19 - 0.75) moles $\mathrm{Fe}^{0}$ become Fe (II). The corresponding half-reactions are as follows:

$$
\begin{aligned}
& \mathrm{NO}_{3}^{-}+10 \mathrm{H}^{+}+8 \mathrm{e}^{-} \rightarrow \mathrm{NH}_{4}^{+}+3 \mathrm{H}_{2} \mathrm{O} \\
& 3 \mathrm{Fe}^{2+}+4 \mathrm{H}_{2} \mathrm{O} \rightarrow \mathrm{Fe}_{3} \mathrm{O}_{4}+2 \mathrm{e}^{-}+8 \mathrm{H}^{+} \\
& 3 \mathrm{Fe}^{0}+4 \mathrm{H}_{2} \mathrm{O} \rightarrow \mathrm{Fe}_{3} \mathrm{O}_{4}+8 \mathrm{e}^{-}+8 \mathrm{H}^{+}
\end{aligned}
$$

Equations [2] and [3] take control at Stage 2, while under acidic conditions, $\mathrm{Fe}^{0} \rightarrow \mathrm{Fe}^{2+}+2 \mathrm{e}^{-}$may be the main reaction. In addition, iron corrosion at near-neutral $\mathrm{pH}$ under anoxic conditions can be represented by the equation $\mathrm{Fe}^{0}+2 \mathrm{H}_{2} \mathrm{O} \rightarrow \mathrm{Fe}^{2+}+2 \mathrm{OH}^{-}+\mathrm{H}_{2}$. Little change in $\mathrm{pH}$ for the control batch Tests 15 and 16, however, suggests that this reaction is slow at $\mathrm{pH} 5.3$ (unadjusted) compared with nitrate-induced iron corrosion. Following mass and charge balance, the overall reaction would be:

$$
\begin{aligned}
& \mathrm{NO}_{3}^{-}+2.82 \mathrm{Fe}^{0}+0.75 \mathrm{Fe}^{2+}+2.25 \mathrm{H}_{2} \mathrm{O} \rightarrow \mathrm{NH}_{4}^{+}+ \\
& 1.19 \mathrm{Fe}_{3} \mathrm{O}_{4}+0.50 \mathrm{OH}^{-}
\end{aligned}
$$

Equations [1] through [4] describe the stoichiometric relationship and do not indicate the specific reaction mechanism(s). Adsorbed $\mathrm{Fe}^{2+}$ (or hydrolyzed adsorbed $\mathrm{Fe}^{2+}$ ) may react with iron (hydr)oxides (e.g., ferrihydrite, lepidocrocite, maghemite) to form intermediates that are transformed to magnetite (Tamaura et al., 1983, 1984; Charlet et al., 1998; Odziemkowski et al., 2000b; Schultz and Grundl, 2000; Vikesland and Valentine, 2000). The overall reaction (Eq. [4]) will be the same because magnetite is the sole end product of iron oxidation in our tests. Deviation from a $\mathrm{Fe}$ (III) to $\mathrm{Fe}$ (II) ratio of 2:1 and/or production of $\gamma-\mathrm{Fe}_{2} \mathrm{O}_{3}, \mathrm{Fe}_{5} \mathrm{HO}_{8} \cdot 4 \mathrm{H}_{2} \mathrm{O}$, or $\gamma$-FeOOH would alter the stoichiometry. Equation [4] indicates that $\mathrm{Fe}^{2+}$ is a contributor but not the primary reductant of nitrate. From a stoichiometric standpoint, $8 \mathrm{~mol}$ of $\mathrm{Fe}^{2+}$ are needed to reduce $1 \mathrm{~mol}$ of nitrate $\left(62 \mathrm{~g} \mathrm{~mol}^{-1}\right)$ or nitrate $\mathrm{N}\left(14 \mathrm{~g} \mathrm{~mol}^{-1}\right)$. This was not observed in our experiments, suggesting that the added $\mathrm{Fe}^{2+}$ is not the major electron donor.

The release of $\mathrm{Fe}^{2+}$ after adding $\mathrm{Fe}^{3+}, \mathrm{Cu}^{2+}$, and $\mathrm{Al}^{3+}$ may result from redox reactions or substitution into the corroding iron matrix (Sidhu et al., 1978; Schwertmann and Cornell, 1991). The added $\mathrm{Fe}^{3+}$ may have simply been reduced to $\mathrm{Fe}^{2+}$ by the $\mathrm{Fe}^{0}$ core but a similar release of $\mathrm{Fe}^{2+}$ was noted when $\mathrm{Al}^{3+}$ was used, suggesting substitution. Immediate release of $\mathrm{Fe}^{2+}$ following addition of $\mathrm{Cu}^{2+}$ may involve a thermodynamically favorable redox reaction between $\mathrm{Fe}^{0}$ and $\mathrm{Cu}^{2+}: \mathrm{Cu}^{2+}+$ $\mathrm{Fe}^{0} \rightarrow \mathrm{Fe}^{2+}+\mathrm{Cu}^{0}$. In fact, metallic $\mathrm{Cu}$ was visible at the end of our experiments in which $\mathrm{Cu}^{2+}$ was added. An alternative or additional mechanism in the presence of $\mathrm{Cu}^{2+}$ involves nitrate reduction by $\mathrm{Fe}^{2+}$ or $\mathrm{Fe}(\mathrm{OH})_{2}$, as demonstrated by Buresh and Moraghan (1976). Unlike our results in which treatment of nitrate with $\mathrm{Fe}^{0}$ and $\mathrm{Fe}^{2+}$ produced $\mathrm{NH}_{4}^{+}$as the primary product,
$\mathrm{NO}_{2}^{-}, \mathrm{N}_{2} \mathrm{O}, \mathrm{N}_{2}, \mathrm{NH}_{2} \mathrm{OH}$, as well as $\mathrm{NH}_{4}^{+}$were found after treating nitrate with $\mathrm{Fe}^{2+}$ and small quantities of $\mathrm{Cu}^{2+}$, with product distribution dependent on $\mathrm{pH}$ (Buresh and Moraghan, 1976; Van Hecke et al., 1990).

While the formation of green rust is a possibility after adding $\mathrm{Al}^{3+}$ because $\mathrm{Al}_{2}\left(\mathrm{SO}_{4}\right)_{3}$ was used (Hansen and Koch, 1998), green rust was not observed in our systems. An abundance of aluminum during $\mathrm{Fe}^{0}$ oxidation promotes its incorporation into the oxidized iron structure (Schwertmann and Cornell, 1991). The smaller ionic radius of $\mathrm{Al}^{3+}$ disrupts crystallization, yielding amorphous iron (hydr)oxide (perhaps as aluminous ferrihydrite; Taylor and Schwertmann, 1978) and facilitating release of $\mathrm{Fe}^{2+}$.

In this study, we observed three stages of nitrate removal if the initial $\mathrm{pH}$ was lowered to 2.3. The acidic $\mathrm{pH}$ in Stage 1 favored removal of passivating (nonconducting) layers from the iron grains, allowed rapid nitrate removal (Stage 1), and enhanced iron dissolution and release of $\mathrm{Fe}^{2+}$ into the bulk solution. As the iron continued to corrode and $\mathrm{pH}$ increased, we observed a surface layer of corrosion products forming on the iron grains (Stage 2). The slow nitrate removal rate observed in Stage 2 could be due to the formation of amorphous iron oxide (Tamaura et al., 1983; Scherer et al., 1998), which passivates the iron surface until $\mathrm{Fe}^{2+}$ is adsorbed and transformed to magnetite. Based on the literature (Scherer et al., 1998), the surface layer of corrosion products will evolve into a mixture of amorphous iron oxides. This thin, unstable layer readily transforms to magnetite and is difficult to detect by X-ray diffraction (Tamaura et al., 1983). As the $\mathrm{pH}$ continued to increase, sustained adsorption and hydrolysis of $\mathrm{Fe}^{2+}$ produced a coating of magnetite on the Fe that resulted in rapid nitrate removal (Stage 3).

Our experimental results are consistent with a $\mathrm{Fe}^{2+}$ adsorption edge at about $\mathrm{pH} 5.5$ (Stage 2) and hydrolysis of adsorbed $\mathrm{Fe}^{2+}$ at $\mathrm{pH} 6.5$ (Stage 3), as reported by Charlet et al. (1998) for $\mathrm{Fe}^{2+}$ adsorption on hematite and magnetite (Vikesland and Valentine, 2000). In our study magnetite was identified as the end product of $\mathrm{Fe}^{0}$ oxidation, consistent with previous research demonstrating magnetite formation following $\mathrm{Fe}(\mathrm{II})$ adsorption on $\gamma$-FeOOH (Tamaura et al., 1983) and iron oxide colloids in solution (Tronc and Jolivet, 1984). Because $\mathrm{Fe}^{2+}$ was prepared from $\mathrm{FeCl}_{2} \cdot 4 \mathrm{H}_{2} \mathrm{O}$, a chloride green rust (GR) may be transiently forming in some of our tests. This GR can reduce nitrate to ammonium with magnetite as the sole Fe oxidation product (Hansen et al., 2000). The highly unstable GR intermediate may not be readily detectable in our experiments.

Given that oxide films will be initially present and evolve with time as the iron corrodes, Scherer et al. (1998) presented three conceptual models for electron transfer at the oxide-iron-water interface: (i) bare iron exposure by pitting, (ii) electron transfer from adsorbed or lattice $\mathrm{Fe}(\mathrm{II})$, and (iii) electron transfer through the conductance bands of semiconducting oxide layers. Our tests with added $\mathrm{Cl}^{-}$(a corroding anion) dismiss pitting as a significant mechanism under the conditions of our 
experiments, because nitrate removal was not accelerated by increasing the $\mathrm{Cl}^{-}$concentration. Electron transfer from adsorbed-lattice $\mathrm{Fe}(\mathrm{II})$ or hydrolyzed $\mathrm{Fe}^{2+}\left(\mathrm{FeOH}^{+}\right)$is a possibility (Klausen et al., 1995; Schultz and Grundl, 2000), but results from our tests showed no nitrate removal when magnetite and $\mathrm{Fe}^{2+}$ were used alone or in combination, within a wide $\mathrm{pH}$ range (Tests 8-10 in Tables 1 and 2). In addition, the stoichiometric relationship between $\mathrm{Fe}^{2+}$ and nitrate does not support $\mathrm{Fe}^{2+}$ as the sole reductant. This leaves electron transfer (semiconductor model) and catalytic hydrogenation via adsorbed atomic hydrogen (Moshtev and Hristova, 1967; Odziemkowski et al., 2000a) as possibilities.

Information generated from this study is important for the application of $\mathrm{Fe}^{0}$-promoted remediation processes. While researchers have been concerned about the inefficiency of $\mathrm{Fe}^{0}$ once iron oxides are formed, our study indicates that under anoxic conditions magnetite will be the product of iron oxidation and the magnetite coating will not hinder nitrate reduction provided sufficient aqueous $\mathrm{Fe}^{2+}$ is present in the system. In situ treatment with permeable iron barriers may be improved by adding $\mathrm{Fe}^{2+}$ to contaminated ground water before it passes through the barrier.

\section{ACKNOWLEDGMENTS}

The authors gratefully acknowledge Dr. J. Betanadhatla, Physics Dep., University of Nebraska-Omaha, for X-ray diffraction analysis, Dr. K.J. Klabunde, Dep. of Chemistry, Kansas State University, for Brunauer-Emmett-Teller surface area analysis, and Dr. K. Lee, School of Biological Sciences, Univ. of Nebraska-Lincoln (UNL) for scanning electron microscopy analysis. This research was supported in part by the USEPA Region 7 and 8 Great Plains-Rocky Mountain Hazardous Substance Research Center (Project 95-32) and EPA/EPSCoR Project R-829422-010. The UNL Center for Infrastructure Research and the Water Center provided matching funds for the project. This paper (no. 13812) is a contribution of Agric. Res. Div. Projects NEB-40-002 and -019.

\section{REFERENCES}

Alowitz, M.J., and M.M. Scherer. 2002. Kinetics of nitrate, nitrite, and $\mathrm{Cr}(\mathrm{VI})$ reduction by iron metal. Environ. Sci. Technol. 36:299-306.

Bremner, J.M., and L.G. Bundy. 1973. Use of ferrous hydroxide for determination of nitrate in soil extracts. Commun. Soil Sci. Plant Anal. 4:285-291.

Bremner, J.M., and K. Shaw. 1955. Reduction of nitrate by ferrous hydroxide under various conditions of alkalinity. Analyst (Cambridge, UK) 80:626-627.

Brown, L.L., and I.S. Drury. 1967. Nitrogen-isotope effects in the reduction of nitrate, nitrite, and hydroxylamine to ammonia. 1 . In solution hydroxide solution with Fe(II). J. Phys. Chem. 46:28332837.

Buresh, R.J., and J.T. Moraghan. 1976. Chemical reduction of nitrate by ferrous iron. J. Environ. Qual. 5:320-325.

Charlet, L., E. Silvester, and E. Liger. 1998. N-compound reduction and actinide immobilization in surficial fluids by $\mathrm{Fe}(\mathrm{II})$ : The surface = $\mathrm{Fe}^{\mathrm{III}} \mathrm{OFe}^{\mathrm{II}} \mathrm{OH}^{\circ}$ species, as major reductant. Chem. Geol. 151:85-93.

Cheng, I.F., R. Muftikian, Q. Fernando, and N. Korte. 1997. Reduction of nitrate to ammonia by zero-valent iron. Chemosphere 35: 2689-2695.

Hansen, H.C.B., and C.B. Koch. 1998. Reduction of nitrate to ammo- nium by sulphate green rust: Activation energy and reaction mechanism. Clay Miner. 33:87-101.

Hansen, H.C.B., C.B. Koch, M. Erbs, S. Guldberg, and J. Dickow. 2000. Redox reaction of iron(II)iron(III) hydroxides (green rusts). p. 321-323. In Division of Environmental Chemistry, preprints of extended abstracts. Vol. 40, no. 2. Am. Chem. Soc., Washington, DC.

Huang, C.P., H.W. Wang, and P.C. Chiu. 1998. Nitrate reduction by metallic iron. Water Res. 32:2357-2364.

Klausen, J., S.P. Trober, S.B. Haderlein, and R.P. Schwarzenbach. 1995. Reduction of substituted nitrobenzenes by Fe(II) in aqueous mineral suspensions. Environ. Sci. Technol. 29:2394-2404.

Matheson, L.J., and P.G. Tratnyek. 1994. Reductive dehalogenation of chlorinated methanes by iron metal. Environ. Sci. Technol. 28: 2045-2053.

Moshtev, R.V., and N.I. Hristova. 1967. Kinetics and mechanisms of the electrode reactions on iron in nitrate solutions. Corros. Sci. 7:255-264.

Odziemkowski, M.S., L. Gui, and R.W. Gillham. 2000a. Reduction of $N$-nitrosodimethylamine with granular iron and nickel-enhanced iron. 2. Mechanistic studies. Environ. Sci. Technol. 34:3495-3500.

Odziemkowski, M.S., L. Gui, R.W. Gillham, and D.E. Irish. 2000 b. The role of oxide films in the reduction of $n$-nitrosodimethylamine with reference to the iron groundwater remediation technology. p. 357-368. In K.R. Hebert, R.S. Lillard, and B.R. MacDougall (ed.) Oxide films. Proc. Int. Symp., Toronto, ON, Canada. 15-18 May 2000. The Electrochemical Soc., Pennington, NJ.

Scherer, M.M., B.A. Balko, and P.G. Tratnyek. 1998. The role of oxides in reduction at the metal-water interface. p. 301-322. In D.L. Sparks and T.J. Grundl (ed.) Mineral-water interfacial reactions: Kinetics and mechanisms. ACS Symp. Ser. 715. Am. Chem. Soc., Washington, DC.

Scherer, M.M., S. Richter, R.L. Valentine, and P.J. Alvarez. 2000. Chemistry and microbiology of reactive barriers for in situ groundwater cleanup. Crit. Rev. Environ. Sci. Technol. 30:363-411.

Scherer, M.M., J.C. Westall, M. Ziomek-Mroz, and P.G. Tratnyek. 1997. Kinetics of carbon tetrachloride reduction at an oxide-free iron electrode. Environ. Sci. Technol. 31:2385-2391.

Schultz, C.A., and T.J. Grundl. 2000. pH dependence on reduction rate of 4-Cl-nitrobenzene by $\mathrm{Fe}(\mathrm{II})$ montmorillonite systems. Environ. Sci. Technol. 34:3641-3648.

Schwertmann, U., and R.M. Cornell. 1991. Iron oxides in the laboratory. VCH Publ., New York.

Siantar, D.P., C.G. Schrefer, and M. Reinhard. 1995. Transformation of the pesticide 1,2-dibromo-3-chloropropane (DBCP) and nitrate by iron powder and by $\mathrm{H}_{2} / \mathrm{Pd} / \mathrm{Al}_{2} \mathrm{O}_{3}$. p. 745-748. In Preprints of papers presented at the ACS 209th national meeting, Anaheim, CA. 2-7 Apr. 1995. Am. Chem. Soc., Washington DC.

Sidgwick, N.V. 1950. The chemical elements and their compounds. Vol. II. Clarendon Press, Oxford.

Sidhu, P.S., R.J. Gilkes, and A.M. Posner. 1978. The synthesis and some properties of $\mathrm{Co}, \mathrm{Ni}, \mathrm{Zn}, \mathrm{Cu}, \mathrm{Mn}$ and $\mathrm{Cd}$ substituted magnetites. J. Inorg. Nucl. Chem. 40:429-435.

Singh, J., S.D. Comfort, and P.J. Shea. 1998. Remediating RDXcontaminated water and soil using zero-valent iron. J. Environ. Qual. 27:1240-1245.

Singh, J., T.C. Zhang, P.J. Shea, S.D. Comfort, L.S. Hundal, and D.S. Hage. 1996. Transformation of atrazine and nitrate in contaminated water by iron-promoted processes. p. 143-150. In Proc. of the Water Environ. Federation 69th Annual Conf. \& Exposition, Dallas, TX. 5-9 Oct. 1996. WEF, Alexandria, VA.

Stucki, J.W. 1988. Structural iron in smectites. p. 625-675. In J.W. Stucki, B.A. Goodman, and U. Schwertmann (ed.) Iron in soils and clay minerals. NATO Advanced Sci. Inst. Ser. D. Reidel Publ. Co., Boston.

Stumm, W. 1992. Chemistry of the solid-water interface: Processes at the mineral-water and particle-water interface of natural systems. John Wiley \& Sons, New York.

Szabo, Z.G., and L.G. Bartha. 1952. The alkalimetric determination of nitrate ion by means of a copper-catalysed reduction. Anal. Chim. Acta 6:416-419.

Tamaura, Y., K. Ito, and T. Katsura. 1983. Transformation of 
$\gamma-\mathrm{FeO}(\mathrm{OH})$ to $\mathrm{Fe}_{3} \mathrm{O}_{4}$ by adsorption of iron(II) ion on $\gamma-\mathrm{FeO}(\mathrm{OH})$. J. Chem. Soc. Dalton Trans. 1983:189-194.

Tamaura, Y., M. Saturno, K. Ymamada, and T. Katsura. 1984. The transformation of $\gamma-\mathrm{FeO}(\mathrm{OH})$ to $\mathrm{Fe}_{3} \mathrm{O}_{4}$ and green rust II in an aqueous solution. Bull. Chem. Soc. Jpn. 57:2417-2421.

Taylor, R.M., and U. Schwertmann. 1978. The influence of aluminum on iron oxides. Part I. The influence of $\mathrm{Al}$ on $\mathrm{Fe}$ oxide formation from the Fe(II) system. Clays Clay Miner. 26:373-383.

Till, B.A., L.J. Weathers, and P.J. Alvarez. 1998. Fe(0)-supported autotrophic denitrification. Environ. Sci. Technol. 32:634-639.

Tronc, E., and J.-P. Jolivet. 1984. Exchange and redox reactions at the interface of spinel-like iron oxide colloids in solution: Fe(II) adsorption. Adsorpt. Sci. Technol. 1:247-251.

Van Hecke, K., O. Van Cleemput, and L. Baert. 1990. Chemo-denitrification of nitrate-polluted water. Environ. Pollut. 63:261-274.

Vikesland, P., and R.L. Valentine. 2000. Iron oxide surface-catalyzed oxidation of ferrous iron by monochloramine: Implications of oxide type and carbonate on reactivity. Environ. Sci. Technol. 36:512-519.

Weber, E.J. 1996. Iron-mediated reductive transformations: Investigation of reaction mechanism. Environ. Sci. Technol. 30:716-719.

Zawaideh, L.L., and T.C. Zhang. 1998. Effects of $\mathrm{pH}$ and addition of an organic buffer (HEPES) on nitrate transformation in $\mathrm{Fe}^{0}$-water systems. Water Sci. Technol. 38:107-115. 